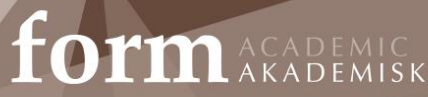

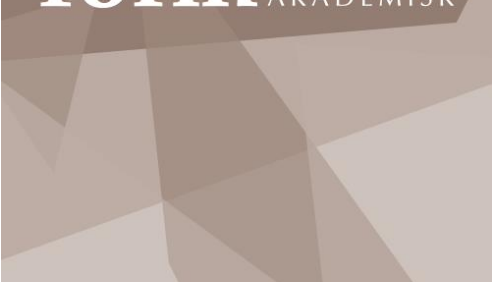

Sirpa Kokko

PhD, Title of Docent

University of Helsinki

sirpa.kokko@helsinki.fi

Vol I4, No 2 (202I)

\title{
Approaches to Craft Studies at Higher Education
}

\begin{abstract}
The purpose of this article is to explore the various approaches to craft studies at higher education institutions. Based on fieldwork observations and document analysis of the curricula of four European and one US university craft study programmes, similarities and differences were found. The similarities concerned the pedagogy to acquire basic skills and the urge to keep up craft traditions. The differences concerned the broader aims of study and the students' prospective career paths. The following approaches to craft studies in higher education were detected: 1. Educational crafts, 2. Traditional crafts, 3. Critical crafts, 4. Cultural heritage of crafts, and 5. Design-based crafts.
\end{abstract}

Keywords:

Craft pedagogy, Higher Education, Craft Science, Art studies, Craft tradition.

\section{INTRODUCTION}

Crafts have entered higher education institutions (HEls) slowly but steadily. The association of crafts as being practical have kept them on the outskirts of the mainstream academy, where theoretical knowledge is valued (Almevik, 2019). However, the conception of what knowing is has changed over time. These days, the knowhow that craft making requires is acknowledged more widely (Groth, 2017). This has supported the entry of crafts into the academia as a field of education and research. However, crafts are taught in different faculties with a range of approaches.

The focus of this article is on the approaches to studying crafts in HEl study programmes. Based on my personal experiences and the fieldwork observations of higher education in crafts in Finland, Estonia, Sweden, the UK and the USA, I have recognised that there are similarities and differences in the way crafts are taught and justified within the academia. For the attempt to outline the nature of approaches to craft studies at HEls, I chose those of which I had pre-understanding.

In the Nordic countries, the educational value of crafts has been recognised for a long time, which is reflected in the status of crafts/sloyd as a school subject. Craft/sloyd at school has required 
specialised teacher education, which in the Nordic countries has been taught within higher education for decades (Johansson, 2018; Porko-Hudd et al., 2018). University-level craft teacher education has paved the way to academic craft research and for developing craft pedagogy. Finland was the first country to establish a specific academic discipline for craft research, namely craft science, which now is an emerging discipline also in the other Nordic and Baltic countries. Craft science is based on a multidisciplinary approach but it will need to develop its own academic ground (Kokko et al., 2020a).

The globalising process has caused many aspects of traditional cultures to merge and become homogenised. As a counterforce to this, actions are taken to keep the local distinct traditions alive and develop them further (Walker et al., 2018). This target has been fundamental for developing a university-level study programme on crafts in Estonia (Kokko, 2018). Another craft study programme in Sweden takes preservation and conservation of the cultural heritage of crafts as its starting point.

Artists have used several forms of crafts as a way to express their ideas and conceptual thinking. Along with this, there is an ongoing debate over the differences and similarities between art and craft (Adamson, 2010). In the artistic approaches, the critical stance is intertwined with the expressive aspect. The critical approach relates to the specific material, technical and socio-cultural dimensions of the particular craft (Kokko, 2021; Wilkinson-Weber \& DeNicola, 2016). This approach was embedded in a US textile/fibre art study programme analysed here.

Design forms a fundamental part of craft production and is essential in a range of study programmes for educating future designers. As this approach has been developed rigorously in the UK, and one of their universities was taken as an example of design orientation in academic craft studies.

\section{METHODS AND DATA}

This is the first attempt to outline the various approaches to craft studies at HEls. The five study programmes on crafts under study were selected according to a snowball method based on my fieldwork when visiting and working in four European and one US study programmes. The purpose of this study is to provide an initiative for a more comprehensive research on the topic. However, the choice of cases followed the ideas of purposeful sampling for maximum variation in the qualitative data collection, as presented by Palinkas et al. (2015). They introduce the criterion for identifying the cases on two bases, emphasising either the similarity or the variation. In this research, both these criteria were used: first, the study programmes were similar in that they focused on crafts in HEls, and second, the purpose of their craft programmes varied. My earlier experiences in working in the chosen study programmes allowed me to develop a good pre-understanding of the nature of craft studies in these study programmes chosen for the investigation. Having experience in the study programmes helped in analysing the official targets presented on each of their websites.

Table 1 summarises the main features of the study programmes, such as their essential approach to crafts, the main purpose of the craft studies, and the faculty and department they are located in the HEl. This general information was gathered from their respective websites on which the study programmes and their official targets are introduced. In addition, the length and time of the fieldwork period is given. Due to the long experience in Finnish craft teacher education as a researcher and a lecturer, the 'fieldwork' period was quite lengthy. Here I refer to leaning on this long experience, which has allowed me to develop a profound understanding of the state of art. The other craft education programmes examined were visited at various times: the length or the fieldwork period ranged from one week to five months at a time. I visited the Estonian HEl several times between 2012-2019, one or two weeks at a time. As my own background is in textile crafts, I often focused on that field, which is indicated in Table 1. Also indicated is when the focus was on other craft fields. 
TABLE 1. The researched HE study programmes on crafts.

\begin{tabular}{|c|c|c|c|c|}
\hline $\begin{array}{l}\text { The HEl and the } \\
\text { country }\end{array}$ & $\begin{array}{l}\text { Faculty/Department at } \\
\text { the HEI }\end{array}$ & $\begin{array}{l}\text { Main approach to } \\
\text { craft studies }\end{array}$ & $\begin{array}{l}\text { Purpose of the } \\
\text { studies. }\end{array}$ & $\begin{array}{l}\text { Fieldwork period. } \\
\text { Particular focus of } \\
\text { analysis on the } \\
\text { study programme. }\end{array}$ \\
\hline $\begin{array}{l}\text { University of Helsinki } \\
\text { (UH) } \\
\text { Finland }\end{array}$ & $\begin{array}{l}\text { Faculty of Educational } \\
\text { Sciences } \\
\text { Department of } \\
\text { Education }\end{array}$ & $\begin{array}{l}\text { craft education } \\
\text { craft pedagogy } \\
\text { craft research }\end{array}$ & educate craft teachers & $\begin{array}{l}7 \text { years, 2013- until } \\
\text { present } \\
\text { Craft Science and } \\
\text { Craft Teacher } \\
\text { Education study } \\
\text { programme }\end{array}$ \\
\hline $\begin{array}{l}\text { James Madison } \\
\text { University (JMU) } \\
\text { USA }\end{array}$ & $\begin{array}{l}\text { Department of } \\
\text { Art, Art History, and Art } \\
\text { Education }\end{array}$ & $\begin{array}{l}\text { critical research with } \\
\text { hands-on making }\end{array}$ & artistic development & $\begin{array}{l}5 \text { months } 2018 \\
\text { focus on textiles } \\
\text { Fibre Art study } \\
\text { programme }\end{array}$ \\
\hline $\begin{array}{l}\text { Viljandi Culture } \\
\text { Academy (VCA), } \\
\text { University of Tartu } \\
\text { Estonia }\end{array}$ & $\begin{array}{l}\text { Department of Estonian } \\
\text { Native Crafts }\end{array}$ & $\begin{array}{l}\text { sustain Estonian } \\
\text { traditional crafts }\end{array}$ & $\begin{array}{l}\text { develop } \\
\text { craftsmanship and } \\
\text { sustain traditional } \\
\text { crafts }\end{array}$ & $\begin{array}{l}\text { Altogether } 6 \text { weeks } \\
\text { 2012-2019 } \\
\text { Estonian Native } \\
\text { Textiles }\end{array}$ \\
\hline $\begin{array}{l}\text { University of } \\
\text { Gothenburg (UG) } \\
\text { Mariestad } \\
\text { Sweden }\end{array}$ & $\begin{array}{l}\text { The Faculty of Sciences } \\
\text { Department of } \\
\text { Conservation }\end{array}$ & $\begin{array}{l}\text { sustain cultural } \\
\text { heritage of crafts }\end{array}$ & $\begin{array}{l}\text { develop } \\
\text { craftsmanship and } \\
\text { sustain cultural } \\
\text { heritage }\end{array}$ & $\begin{array}{l}1 \text { month, } 2018 \\
\text { Construction }\end{array}$ \\
\hline $\begin{array}{l}\text { Manchester } \\
\text { Metropolitan } \\
\text { University } \\
\text { UK }\end{array}$ & $\begin{array}{l}\text { Department } \\
\text { Manchester School of } \\
\text { Art }\end{array}$ & design & educate designers & $\begin{array}{l}1 \text { week, } 2017 \\
\text { Product Design and } \\
\text { Craft }\end{array}$ \\
\hline
\end{tabular}

The document analysis method was used (Bowen, 2009; Jupp \& Norris, 1993) to analyse the curricula of the study programmes. This method concerns the actual contents of those documents (Jupp \& Norris, 1993). The curricula meet the requirements of the document analysis in terms of their authenticity, representativeness and credibility (Fitzgerald, 2012). The analysis was guided by the following questions: What is the structure of the study programme? What are the targets of the study programme? What are the career prospects after finishing the study programme? What pedagogical methods are used? The answers to these questions were searched for in the curricula of the five study programmes laid out on their respective websites. Table 2 (at the end of this article) presents the curricula analysis in a nutshell.

During the fieldwork periods, I relied on an ethnographic approach including participatory observation. I wrote field notes, gathered a range of other material, such as seminar presentations, lectures, course assignments, and took photographs. As the time spent in the field ranged from one 
week to several years, the amount of data varied from a few pages of field notes and few photographs to data that were more extensive. However, this qualitative data was used mainly to enliven the curricula to be analysed by practical examples of activities.

\section{APPROACHES TO CRAFT STUDIES}

Both similarities and differences were found concerning the way the studies were arranged and implemented. The similarities involved learning basic craft skills and the urge to keep up the craft traditions and strengthen the status of crafts in the academy. The study programmes differed in their broader aims and in the prospective career paths that could be followed by the students in each. In addition, the skill acquisition levels varied. The purpose of each study varied from personal development to developing skills to support others as teachers. In addition, the purpose ranged from aiming to create a material-based creative business to sustaining craft heritage and traditions. This initial analysis of the study programmes revealed the following approaches to craft studies in higher education: 1 . Educational crafts, 2. Traditional crafts, 3. Critical crafts, 4. Craft heritage, and 5. Design-based crafts. Each of these is discussed below, along with a consideration of the relevant research literature.

\section{Educational crafts}

For the purposes of this study, one Finnish craft teacher education programme was analysed. According to its curriculum, the purpose is to give the students enough hands-on skills and pedagogical understanding and competence to teach crafts. Thus, the purpose is to educate professionals in both education and crafts. As all the students complete a BA and an MA, including writing a respective thesis, craft research skills are emphasised.

Due to recent changes in the Finnish National Core Curriculum for Basic Education, crafts is now a 'multimaterial' subject; pupils use the techniques and materials of former textile and technical craft fields upon their own design processes. This is reflected in craft teacher education, which has turned to multimaterial craft-specific study, rather than former textile or technical craft specific studies. Contentspecific craft has diminished and the students work more on multimaterial projects (Kokko et al., 2020b). Based on the curriculum and leaning on my observations in craft teacher education, group work methods and collaborative projects now prevail in the pedagogy. Since the time allocated to hands-on contact lessons is constantly diminishing, the students are practising hands-on skills and doing their course assignments independently or with peer support.

As the purpose is to educate craft teachers, about $20 \%$ of the studying is dedicated to pedagogical studies, consisting of a range of curriculum, pedagogy, didactics, assessment, psychology, philosophy and sociology of education studies. These are often arranged as lectures. Some topics are studied more deeply in seminars, in which the students complete a range of related assignments. Often the students are required to do some background reading and produce their own application of the topic, such as practical tools to implement the assessment of learning outcomes. An essential part of the pedagogical studies consists of teaching practice in which the students plan, implement and reflect on their teaching at basic and adult education under supervision. They are required to produce a portfolio of these activities.

\section{Traditional crafts}

The Estonians managed to maintain their own cultural traditions under the Soviet rule; keeping up with the Estonian identity is important for this small country (Annist, 2009). One sign of this is the study programme for native crafts at the University of Tartu. The curriculum of Estonian native textiles was chosen as an example for this research. In the BA programme, the purpose is to "educate professional and creative master craftsmen with a thorough knowledge of Estonian native textile heritage, its history, compositional techniques and technology and the ability to keep, continue and re-use the traditions of Estonian native handicraft in the field of textile".

After completing their programme, the prospective fields of work are outlined as entrepreneurs, museum workers, artists and designers. The study programme consists of lectures, 
individual studying, working in the archives and hands-on skill building. The focus is always on the Estonian craft tradition and heritage. The BA is arranged mainly as a full-time programme at the university, lasting four years. Towards the end of a BA programme, the students complete a thesis consisting of both a practical crafted part and a theoretical textual part.

There is also an option for a two-year MA programme, which is partly arranged as distant education. The students deepen their hands-on skills in their chosen craft topic, for example, a craft material, technique, object, or craft as a cultural phenomenon. They also conduct theoretical research on this craft topic and produce an MA thesis combining the practical and theoretical elements. Often the thesis includes photographs, charts, drawings and other visual material. Some of the MA theses are shortened and published in the university's academic journal Studia Vernacula (2019).

Based on my fieldwork in this Estonian university at different times (Table 1), I have good grounds for claiming that the students develop deep hands-on skills in a particular craft. Thus, they get good skills for working on that specific craft field in the future (Kokko, 2018). Some of the crafted products are astonishingly large, such as a traditional smoke sauna as one MA project (Studia Vernacula, 2019). The students conduct rigorous fieldwork by visiting the masters in that craft, even in remote areas such as the Estonian islands or even Russia. Working in the archives is an essential part of the programme. Both the BA and MA theses go through a rigorous open defence during which the students present their work to the jury and defend it by answering the questions.

\section{Critical crafts}

Quite a different stance to crafts is taken in the art-oriented craft studies. During the five months that I spent in the USA in 2018, I conducted ethnographic research on a critical research approach in textile art studies at a US university (Kokko, 2021). According to the curriculum, the purpose was to explore "materials within a contemporary context that considers emergent and related issues of multiculturalism, technological advancement, gender, sexuality and more". The study programme includes both studio practice and critical research on the various issues related to textiles, their material, process and the maker, as well as the history of the global economic marketplace. The curriculum names some of the textile techniques to be studied, namely weaving and off-loom processes like wet felting, spinning, knitting, crochet, surface design, stitch and screen-printing.

Based on my observations and field notes, reading assignments and lectures were used as a basis for discussions about the above-mentioned topics during the lessons. The students were required to practise certain techniques so that they could apply them in their craftwork, which needed to have an idea, a message or a statement (Kokko, 2021). While working on their hands-on assignments, the students searched for information related to the specific material and technique.

The teacher explained that the approach to critical craft consisted of three elements: (1) intersectionality and interconnectedness, (2) the material context, and (3) the process. Intersectionality and interconnectedness referred to the crafts being interconnected with cultural and historical understanding. The material context meant raising various questions about the material's roots in place and time. By the process, the teacher referred to the meaning of the making when the process informs the work and is more important than the actual product. In addition to discussing the topics during the lessons, the students connected the elements of critical research to their hands-on activities in their written assignments.

During my fieldwork observations, I recognised that textile craft techniques with related materials and equipment were taught with principles similar to those familiar to me in other craft education contexts both in Finland and abroad. However, unlike the craft study focused on the craftsmanship, the approach was to learn the skills only to use them in artistic expression. Thus, the meaning was valued over the skill, which was reflected in the course assessment, in which a high level of skills was not central.

\section{Cultural heritage of crafts}

Sometimes it is hard to find the craft to study at the HEI, since the various crafts are located in various departments. The Swedish craft study programme under study here, is situated in the Faculty of Science, 
Department of Conservation at the University of Gothenburg. I found this to be odd, since crafts are often located within departments of arts, design or education. During my fieldwork in April 2018, I discovered that the study programme for cultural conservation had even established a field of academic discipline, craft science, which covered a range of activities in which hands and tacit knowledge was used (Almevik, 2019; Almevik et al., 2014). The fundamental ideology seemed to lie in learning about the tacit knowledge of traditional crafts to revitalise and acquire them in the present time.

In the cultural conservation study programme, there are four BA level programmes (Table 2). During my fieldwork, I observed activities in each of them. For the purpose of this article, I chose the building crafts programme curriculum for the analysis. According to the curriculum, the aim is to develop the students' practical and theoretical skills in the building crafts. The students acquire a good basis for practical craftsmanship in the workshops, projects, and during their internship periods. They also learn to conserve the old buildings. The studies include cultural history and research methods. During my fieldwork, I observed that the students were active in the well-equipped workshops where they seemed to acquire professional building techniques under supervision both individually and collaboratively. I also learned that they had been involved in projects restoring old buildings with cultural historical value, often learning the traditional crafting skills to be used in the restoration.

In addition to the BA and MA study programmes, the department has been active in connecting the craftspeople with the research by establishing The Craft Laboratory in cooperation with universities, heritage organisations, craft enterprises, and trade organisations. The purpose has been to bring research into practice and involve craftspeople in the processes of inquiry (Almevik, 2016). According to the results, this specific initiative deserves to be adapted more widely.

TABLE 2. The study programmes under study. The questions guiding the document analysis.

\begin{tabular}{|c|c|c|c|}
\hline $\begin{array}{l}\text { HEI } \\
\text { Name of the study } \\
\text { programme }\end{array}$ & $\begin{array}{l}\text { What is the structure of the } \\
\text { study programme? }\end{array}$ & $\begin{array}{l}\text { What are the career } \\
\text { prospects after finishing the } \\
\text { study programme? } \\
\text { What are the targets of the } \\
\text { study programme? }\end{array}$ & $\begin{array}{l}\text { What pedagogical methods } \\
\text { are used? }\end{array}$ \\
\hline $\begin{array}{l}\text { UH } \\
\text { Craft Science and Craft } \\
\text { Teacher Education }\end{array}$ & $\begin{array}{l}\text { BA + MA } 300 \text { ECTS } \\
\text { ( } 3 \text { years }+2 \text { years })\end{array}$ & $\begin{array}{l}\text { To qualify as an expert of } \\
\text { education, teaching, learning } \\
\text { and craft field. } \\
\text { Multimodality, } \\
\text { interdisciplinary and } \\
\text { research. } \\
\text { The central objectives are to } \\
\text { be support crafts and } \\
\text { craftsmanship as part of the } \\
\text { basic education and of } \\
\text { lifelong learning. } \\
\text { In Craft Science research } \\
\text { skills, there is a range of } \\
\text { topics concerning the } \\
\text { interaction, manufacturing, } \\
\text { scientific thinking, } \\
\text { multimaterial problem } \\
\text { solutions, ethics and } \\
\text { sustainable future, craft } \\
\text { culture. }\end{array}$ & $\begin{array}{l}\text { Option to focus more } \\
\text { broadly on some area of the } \\
\text { crafts. } \\
\text { The pedagogy contains } \\
\text { lectures, individual and } \\
\text { collaborative work, essay } \\
\text { writing, exams, testing of } \\
\text { materials, hands-on } \\
\text { activities on a range of } \\
\text { materials and techniques, } \\
\text { independent research work, } \\
\text { and projects. Pedagogical } \\
\text { studies and teaching } \\
\text { practice. Portfolios. }\end{array}$ \\
\hline
\end{tabular}




\begin{tabular}{|c|c|c|c|}
\hline $\begin{array}{l}\text { JMU } \\
\text { Fibre Arts \& Weaving }\end{array}$ & $\begin{array}{l}\text { B.F.A. Art Studio ( } 4 \text { years): } \\
\text { fibre art concentration forms } \\
15 \text { credits part of } 78 \text { credits. } \\
\text { Also possible to include } \\
\text { some fibre art courses as part } \\
\text { of the B.F.A } \\
+ \text { MFA in fibres ( } 3 \text { years, } 60 \\
\text { credits) }\end{array}$ & $\begin{array}{l}\text { The students will qualify as } \\
\text { artists, teachers, graphic } \\
\text { designers, photographers } \\
\text { etc. } \\
\text { The fibre arts program } \\
\text { emphasizes exploration of } \\
\text { materials within a } \\
\text { contemporary context that } \\
\text { considers emergent and } \\
\text { related issues of } \\
\text { multiculturalism, } \\
\text { technological advancement, } \\
\text { gender, sexuality and more. }\end{array}$ & $\begin{array}{l}\text { Students examine the } \\
\text { relationships among } \\
\text { material, process and the } \\
\text { maker, as well as the critical } \\
\text { role that cloth and fibre } \\
\text { processes have played in } \\
\text { global economic } \\
\text { marketplaces historically. } \\
\text { Student engagement in both } \\
\text { in studio practice and critical } \\
\text { research. } \\
\text { Students learn to weave on- } \\
\text { loom while also being } \\
\text { introduced to many off-loom } \\
\text { processes like wet felting, } \\
\text { spinning, knitting, crochet, } \\
\text { surface design, stitch and } \\
\text { screen-printing. } \\
\text { Studio sessions are } \\
\text { supplemented with readings } \\
\text { and discussion that explore } \\
\text { social and cultural concerns } \\
\text { related to the techniques } \\
\text { learned. } \\
\text { Experimenting with } \\
\text { materials and methods is } \\
\text { encouraged as students } \\
\text { develop individual creative } \\
\text { practices. } \\
\text { Contemporary artists and } \\
\text { curators conduct studio } \\
\text { visits with students }\end{array}$ \\
\hline $\begin{array}{l}\text { VCA } \\
\text { Estonian Native Crafts: } \\
\text { Estonian Native Textiles }\end{array}$ & $\begin{array}{l}\text { BA } 240 \text { ECTS (4 years) on } \\
\text { Estonian Native Crafts. } \\
\text { Concentration on Estonian } \\
\text { Native } \\
\text { Textile } \\
\text { Construction } \\
\text { Metalwork } \\
+ \text { optional MA } 120 \text { ECTS ( } 2 \\
\text { years) }\end{array}$ & $\begin{array}{l}\text { The graduates will be able, to } \\
\text { run small enterprises, work } \\
\text { as artists, textile designers, } \\
\text { museum workers or } \\
\text { manufacturers of leather } \\
\text { items or folk costumes. } \\
\text { The aim of the Native Textile } \\
\text { speciality is to educate } \\
\text { professional and creative } \\
\text { master craftsmen with a } \\
\text { thorough knowledge of } \\
\text { Estonian native textile } \\
\text { heritage, its history, } \\
\text { compositional techniques } \\
\text { and technology and the } \\
\text { ability to keep, continue and } \\
\text { re-use the traditions of }\end{array}$ & $\begin{array}{l}\text { The use of the Estonian } \\
\text { ethnographical textile } \\
\text { heritage as a source material } \\
\text { for our studies. } \\
\text { Interpreting archival } \\
\text { sources, independent study } \\
\text { of folkloristic, independent } \\
\text { research, seminar } \\
\text { presentation, portfolios. }\end{array}$ \\
\hline
\end{tabular}




\begin{tabular}{|c|c|c|c|}
\hline & & $\begin{array}{l}\text { Estonian native handicraft in } \\
\text { the field of textile. }\end{array}$ & \\
\hline $\begin{array}{l}\text { UG, Mariestad } \\
\text { Department of Cultural } \\
\text { Conservation } \\
\text { The Building Crafts } \\
\text { programme }\end{array}$ & $\begin{array}{l}\text { Cultural Conservation } \\
\text { BA } 180 \text { ECTS + } \\
\text { optional MA Master's } \\
\text { Program } 120 \text { ECTS } \\
\text { BA programmes: } \\
\text { Building Crafts } \\
\text { The Craft of Garden and } \\
\text { Landscape Care } \\
\text { Building antiquarian } \\
\text { The Conservator }\end{array}$ & $\begin{array}{l}\text { The individual opportunities } \\
\text { focus on future professional } \\
\text { careers ranging from } \\
\text { academia to construction } \\
\text { industry. } \\
\text { There is a great need for } \\
\text { carpenters and bricklayers } \\
\text { with knowledge and } \\
\text { understanding of old houses } \\
\text { and traditional } \\
\text { craftsmanship. } \\
\text { The aim of the training is to } \\
\text { create developers who not } \\
\text { only have practical skills in } \\
\text { the traditional craft, but also } \\
\text { have the theoretical skills and } \\
\text { communicative ability to } \\
\text { interact with other } \\
\text { professionals in the field. }\end{array}$ & $\begin{array}{l}\text { The building crafts program } \\
\text { develops practical and } \\
\text { theoretical skills to work in } \\
\text { buildings or new production } \\
\text { using traditional and } \\
\text { artisanal methods. } \\
\text { The training alternates } \\
\text { between theory and practice } \\
\text { and concludes with a } \\
\text { bachelor's degree with } \\
\text { specialization in } \\
\text { construction crafts. } \\
\text { The training includes } \\
\text { familiarization with the } \\
\text { historically most common } \\
\text { building techniques through } \\
\text { practical exercises. The } \\
\text { students develop their } \\
\text { understanding of } \\
\text { conservation based on } \\
\text { cultural historical and } \\
\text { sustainable perspectives. } \\
\text { The studies include } \\
\text { internship periods in } \\
\text { companies active in the } \\
\text { industry. } \\
\text { Some courses use case } \\
\text { studies or projects, while } \\
\text { others are based on } \\
\text { lectures, field trips, } \\
\text { excursions and field work. } \\
\text { Individual research work and } \\
\text { individual assignments as } \\
\text { well as collaborative work. }\end{array}$ \\
\hline $\begin{array}{l}\text { MMU } \\
\text { Product Design and } \\
\text { Craft }\end{array}$ & $\begin{array}{l}\text { BA (Hons) 3-year degree } \\
\text { qualification typically } \\
\text { comprises of } 360 \text { credits. } \\
\text { optional MA } 1 \text { year in a range } \\
\text { of topics. } \\
\text { There are about } 10 \text { design- } \\
\text { oriented BA level study } \\
\text { programmes at MMU. }\end{array}$ & $\begin{array}{l}\text { Graduates go on to establish } \\
\text { their own creative businesses } \\
\text { as self-employed } \\
\text { practitioners, or pursue } \\
\text { careers as product designers, } \\
\text { furniture designers, } \\
\text { ceramicists, jewellers, } \\
\text { retailers, gallery owners, } \\
\text { retail buyers, design } \\
\text { managers, design } \\
\text { consultants, teachers and } \\
\text { lecturers. } \\
\text { The study programme has a } \\
\text { material-led, experimental } \\
\text { philosophy that pursues a } \\
\text { thinking through making }\end{array}$ & $\begin{array}{l}\text { Combination of lectures, } \\
\text { seminars and practical } \\
\text { sessions, and independent } \\
\text { study. } \\
\text { Designing and producing } \\
\text { objects that embrace both } \\
\text { traditional handmade } \\
\text { approaches and } \\
\text { contemporary machine and } \\
\text { digital manufacturing. } \\
\text { Creative experimentation to } \\
\text { give ideas a material voice. } \\
\text { Provides a designer/maker } \\
\text { focus, pursuing } \\
\text { experimental approaches } \\
\text { that are often driven by } \\
\text { individual responses to }\end{array}$ \\
\hline
\end{tabular}




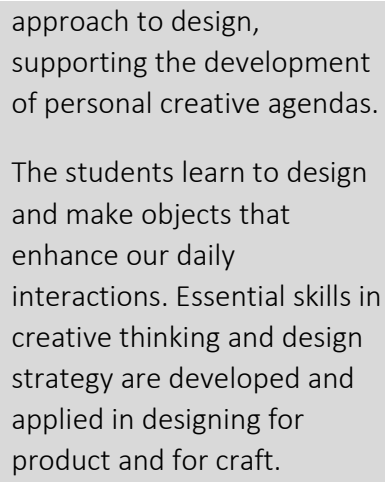

social, political and environmental issues in the creation of the designed object.

A range of workshops for hand and machine making in ceramics, glass, metal, wood and plastics, digital making facilities for CNC routing, 3D printing and laser cutting.

\section{Design-based crafts}

My visit to the UK design-based HEls is the shortest of the cases introduced in this article and thus the findings are tentative. However, as design is so fundamental in craft studies and there are many study programmes on design, I wanted to include this approach in the analysis.

I visited Manchester Metropolitan University to participate in a final conference of the Design Roots project (Walker et al., 2018) and had an opportunity to visit their study programmes in design.

For the purpose of this article, I chose the curriculum of their BA level Product Design and Craft study programme for the analysis. According to the curriculum, "The study programme has a materialled, experimental philosophy that pursues a thinking through making approach to design, supporting the development of personal creative agendas". The teaching combines lectures, seminars and practical sessions, and independent study under the supervision of experienced and practicing designers. According to the curriculum - and based on my own observations - the students study hands-on skills in a range of workshops. The purpose of this is to equip the students with qualifications that allow them to pursue a range of career paths from self-employed practitioners to design consultants and lecturers. The focus is on personal development supporting the students to find their own strengths and motivations. According to the curriculum, broader global issues are part of the design studies. This was confirmed in my fieldwork period as I observed, the students included cultural and ecological aspects in their craft design. Often the idea seemed to be to combine the students' personal ideas into product design, keeping in mind the marketability.

\section{CONCLUSIONS}

Crafts have gained more status in HEls due to increased interest in their research (Niedderer \& Townsend, 2010) and changes in the views about what knowledge is. However, what is the relationship between the theory and practice is topical when crafts enter the academia (Almevik, 2019). The initial analysis of the study programmes on crafts in HEls presented in this article revealed the following approaches to craft studies: 1. Educational crafts, 2. Traditional crafts, 3. Critical craft, 4. Cultural heritage of crafts, and 5. Design-based crafts. The conclusions were based on document analysis of five study programmes and the material gathered during the periods of fieldwork. The purpose of the study was to provide a starting point for exploring the range of approaches more extensively, preferably by a joint research project through which more exhaustive document analysis and a variety of research methods could be applied.

The differences between the approaches were visible in the requirements concerning the level of skill acquisition and the extent to which craft traditions were followed or modified. The educational purpose differed from acquiring the competencies to establish a small-scale craft enterprise to commercial success and industrial production as the targets. There were differences in whether the study programme focused on the students' personal artistic growth or on providing them with enough skills as teachers to support the growth of their future students. 
Notwithstanding the differences, some common elements were shared. First, craft activities concerned hands-on making. This requires skills which are learned through practising them and are often taught using similar pedagogical principles. Second, all the approaches were dedicated to strengthening the understanding and appreciation of crafts, which is often considered to be inferior to the more traditional academic disciplines. Third, although the focus on tradition differed, concern about losing craft traditions and dedication to keep them was common in all the craft study programmes analysed.

In this article, I have attempted to highlight that there are many approaches to studying craft at HEls. Choice of the five craft study programmes was based on my own familiarity with them. On the one hand, due to my prior knowledge I had a lively picture of the activities in each of them, which helped in analysing their official targets. On the other hand, the period of my fieldwork ranged from one week to several years, and this inevitably affects the view I had developed of the study programmes. It is thus clear that further research including more study programmes is required to test the validity of the approaches revealed in this paper. However, for crafts to flourish in higher education, it is beneficial for the educators and researchers to be aware of the range of approaches to craft studies other than the one practised in their own department. At best, craft educators and researchers share views and good practices adding new elements to their own work. Recognising the value of distinctive approaches will strengthen the academic status of crafts. 


\section{REFERENCES}

Adamson, G. (2010). The Craft Reader. Berg.

Almevik, G. (2019). Hantverksvetenskap och vetenskapligt hantverk. FormAkademisk, 12(1), 1-14. https://doi.org/10.7577/formakademisk.2310

Almevik, G. (2016). From Archive to living Heritage. Participatory documentation methods in crafts. In A. Palmsköld,J. Rosenqvist, \& G: Almevik (Eds.), Crafting Cultural Heritage (pp. 77-99). Gothenburg University Press. http://hdl.handle.net/2077/42095

Almevik, G., Höglund, S., \& Winbladh, A. (Eds.). (2014). Hantverkare emellan. Mariestad Craft Laboratory.

Annist, A. (2009). Outsourcing Culture: Establishing Heritage Hegemony by Funding Cultural Life in South Eastern Estonia. Lietuvos Etnologija: socialinés antropologijos ir etnologijos studijos, 9(18), 17-138. https://talpykla.istorija.It/bitstream/99999/2005/1/Lietuvos_etnologija_9\%2818\%29_117-138.pdf

Bowen, G. A. (2009). Document Analysis as a Qualitative Research Method. Qualitative Research Journal, 9(2), 27-40. https://doi.org/10.3316/QRJ0902027

Fitzgerald, T. (2012). Documents and document analysis. In A.R.J Griggs, M. Coleman, \& M. Morrison (Eds.), Research Methods in Educational Leadership \& Management (pp. 296-308). SAGE. http://dx.doi.org/10.4135/9781473957695.n20

Groth, C. (2017). Making Sense through Hands: Design and Craft Practice Analyzed as Embodied Cognition. ( Aalto University publication series 1/2017) [Doctoral Dissertation]. Aalto Arts books.

Johansson, M. (2018). Doktorsavhandlingar inom det nordiska slöjdfältet [Doctoral theses in the Nordic craft field]. Techne Serien A, 25(3), 109-123.

https://journals.oslomet.no/index.php/techneA/article/view/3031

Jupp, V., \& Norris, C. (1993). Traditions in documentary analysis. In M. Hammersley (Ed.), Social Research. Philosophy, Politics and Practice (pp. 37-51). SAGE.

Kokko, S. (2018). The role of higher education in sustaining culturally significant crafts in Estonia. In S. Walker, M. Evans, T. Cassidy, A. T. Holroyd, \& J. Jung (Eds.), Design Roots. Culturally Significant Designs, Products and Practices (pp. 231-242). Bloomsbury Academic. https://doi.org/10.5040/9781474241823.ch-022

Kokko, S. (2021). Critical research approach in craft and fibre art studies in the USA. International Journal of Education Through Art. (accepted for publication)

Kokko, S., Almevik, G., Høgseth, H., \& Seitamaa-Hakkarainen, P. (2020a). Mapping the methodologies of the Craft Sciences in Finland, Sweden and Norway. Craft Research, 11(2), 177-209. https://doi.org/10.1386/crre_00025_1

Kokko, S., Kouhia, A., \& Kangas, K. (2020b). Finnish craft education in turbulence. Techne serien - Forskning $i$ Slöjdpedagogik och Slöjdvetenskap, 27(1), 1-19. https://journals.oslomet.no/index.php/techneA/article/view/3562

Niedderer, K., \& Townsend, K. (2010). Editorial. Craft Research, 1(1), 3-10. https://doi.org/10.1386/crre.1.3_2.

Palinkas, L. A., Horwitz, S. M., Green, C. A., Wisdom, J. P., Duan, N., \& Hoagwood, K. (2015). Purposeful sampling for qualitative data collection and analysis in mixed method implementation research. Administration and policy in mental health and mental health services research, 42(5), 533-544. https://doi.org/10.1007/s10488-013-0528-y

Porko-Hudd, M., Pöllänen, S., \& Lindfors, E. (2018). Common and holistic crafts education in Finland. Techne Serien A, 25(3), 26-38. https://journals.oslomet.no/index.php/techneA/article/view/3025

Studia Vernacula (2019). Volume 10. All things considered. Viljandi Culture Academy. http://ojs.utlib.ee/index.php/SV/issue/view/1220

Walker,S., Evans, M., Cassidy, T., Holroyd, A. T., \& Jung, J. (Eds.). (2018), Design Roots. Culturally Significant Designs, Products and Practices. Bloomsbury. https://doi.org/10.5040/9781474241823

Wilkinson-Weber, Clare M., \& DeNicola, Alicia O. (Eds.). (2016). Critical Craft: Technology, Globalisation, and Capitalism. Bloomsbury. 